\title{
Design Analysis Of CFR - ACP Gates For Reservoirs
}

\author{
Dabbiru Ravi VIkranth ${ }^{1}$, K.Sarath Chandra ${ }^{2}$ \\ Associate Professor ${ }^{1}$, Assistant Professor ${ }^{2}$, \\ Dept. of Mechanical Engineering, SVP Engineering College, Visakhapatnam ${ }^{1,2}$ \\ vjdabbiru@gmail.com ${ }^{1}$, sarathchandrakms@gmail.com ${ }^{2}$
}

\begin{abstract}
Conserving water resources inter alia optimal utilization for both agricultural and drinking water purposes is the need of the hour. Depleting water resources, project a grim picture wherein rain fed agricultural production accounts to more than $60 \%$ of the total produce in INDIA. Current hydro graphic data suggests, it could not be far away before dams/ reservoirs to be fed with desalinated water for drinking purposes and rain fed water for agricultural purposes. The paper discusses about, utilizing Aluminium Composite Panel (ACP) and Carbon Fibre Reinforced Polymer (CFRP) gate materials sustaining peak stresses, loads from the dam/ reservoirs with factor of safety ranging between $5-8$. The gates are designed to resist Corrosion, chemical, Icing Effects from desalinated water resources. Composite gate materials are experimentally tested (destructive) using Universal Testing Machine, Impact Testing etc. CFRP is observed to improve the shock resistance, buckling under varying loads, varying high energy waves etc. The ACP enhances the overall structural strength requirements. Optimal Ply Angle of $28.5^{0}$ is observed to improve the axial and shearing loads. By impregnating ACP with CFRP; a Non - Corrosive, Steady, Fire Resistant, light weight, economical, easy to use composite gates can be achieved.

An Internet of Things (IoT) enabled lifting mechanism ${ }^{[1]}$ is designed for efficient control and demand based optimal closing/ lifting of gates. Hoisting assembly for dam gates are made of Carbon Fiber Composites which include speed reduction gear mechanism (tracked wheels) that contribute immensely in the reduction of torque and reduces the effort required to lift the gate. The core material is used to increase the stiffness and strength of the entire panel and can be used according to the application or the area of use. Structural, fatigue analysis is done on the assembly to compare the deformations, stresses and frequencies between the materials.Various tests like Three point bending test, tensile and compressive tests carried out in order to validate the design. After the tests are conducted the obtained results and values are compared and graphs were plotted to compare the various Bending, Tensile and Compressive Load bearing capacity of the various sandwich panels prepared with varying core materials. Polyurethane with acrylite based sandwich panels tend to have better tensile and compressive load bearing capacity as compared to Aluminium Honeycomb due to their structure and Aluminium has better flexural properties because of its core line up which can undertake bending easily.
\end{abstract}

Keywords: CFRP, polymer composites, aluminium composite, AL7075, Radial Gates, Vertical Lift Gates, ACP

\section{INTRODUCTION:}

A dam refers to a barrier designed to withhold water or regulate underground water channels. Dams created in a given area have many uses and are sometimes referred to as multi-purpose projects. Dams can be used for industrial applications, irrigation, domestic use, navigation and aquaculture. For many dams, however, its primary function has been the generation of Hydro-electric power. Dams can also be used to store water meant for long term use, or reserved for dry seasons. Essentially, dams are mainly used for water retention while dikes and floodgates are used to prevent and manage water flow in order to prevent spill overs that could cause adverse effects to the populations living around the dam.

Reservoirs on the other hand are water holding structures. Their primary purpose is to regulate the inflow and outflow from one dam onto another or terminal usage. Rural Reservoirs are used either in diversion canals, balancing, lift irrigation schemes etc. While Urban Reservoirs are used to cater to the industrial, drinking water demands of the urban population. Dam/ Reservoir Gates - function as controlling delivery head through which the stored water resources are let out of the system. Radial Gates are predominantly used while Vertical lift gate systems are seldom being used nowadays. Both gates are being discussed in this paper owing to their prominence.

The water table in both urban and rural areas had shown significant drop especially in Visakhapatnam District, Andhra Pradesh State, INDIA. The water table had sharply fallen from $5 \mathrm{~m}$ to $15 \mathrm{~m}$ (average) during the past decade. Rapid urbanization, encroachments into water bodies, asynchronous rain fall with agricultural crop cycle, rampant depletion of natural resources are some of the reasons. The current picture poses a grim reality of depriving water needs to the residents, agricultural demands, industrial establishments of the district. Main feeder lines are canals from Godavari River through Yeluru Canal, Raivada canal etc. Drinking water supply is through Meghadrigedda, Kanithi Balancing Reservoir etc. Unfortunately, Meghadrigedda\&Kanithi Balancing Reservoir have reached Dead Storage level in the month of December' 2018. With summer approaching; to cater to the demands of various stake holders; - civic authorities are facing uphill task to meet the demands v/s supply. Civic authorities; looking at available avenues to cater to the demands.

Problems stated; solution awaits in utilizing the Desalination plants. The paper discusses about using FRA gates (vertical lift and radial) for dams/ reservoirs under discussion. To summate the research, a model dam with reservoir \& delivery system is undertaken for analysis.

\section{FORCES ACTING ON THE DAMS/ RESERVOIRS ${ }^{[5]}$ :}

Uplifting forces, hydrodynamic forces, Silt Forces, wave forces, quake forces etc. act on the dam structure. Ice Pressure is neglected as, the recorded minimum temperature for the past century is above $14^{0} \mathrm{c}$. For sake of simplicity, the 


\section{International Journal of Research in Advent Technology, Vol.7, No.3, March 2019}

$$
\text { E-ISSN: 2321-9637 }
$$

\section{Available online at www.ijrat.org}

forces acting on the dam along the horizontal and vertical axis.

$$
\begin{aligned}
& \Sigma \mathrm{F}_{\mathrm{x}}=\mathrm{F}_{\text {hydro dynamic }}+\mathrm{F}_{\text {wave }}+\mathrm{F}_{\text {ice }}+\mathrm{F}_{\text {Earth }+} \mathrm{F}_{\text {Silt }-\mathrm{X}} \\
& \Sigma \mathrm{F}_{\mathrm{y}}=\text { Fweight }- \text { Fupward }-\mathrm{F}_{\text {Earth }}-\mathrm{F}_{\text {Silt }-} \mathrm{y} \\
& \therefore \mathrm{F}_{\text {res. }}=\sqrt{ }\left[\left(\Sigma \mathrm{F}_{\mathrm{y}}\right)^{2}+\left(\Sigma \mathrm{F}_{\mathrm{y}}\right)^{2}\right]
\end{aligned}
$$

a. Hydrodynamic Pressure: The pressure created by the Water head at the inlet to the dam. Uniform Varying load with atmospheric pressure at the top level of the $\mathrm{dam} /$ reservoir and maximum loading at the bottom end is assumed. The center of gravity for a triangular loading is assumed to be at a height of $1 / 3^{\text {rd }}$ of its overall height.

Pressure $(\mathrm{P})=\Upsilon_{\mathrm{w}} \times \mathrm{H}^{2} / 2$

Here,

$$
\Upsilon_{\mathrm{w}}=9.81 \mathrm{kN} / \mathrm{m}^{3}=1000 \mathrm{kgf} / \mathrm{m}^{3}
$$

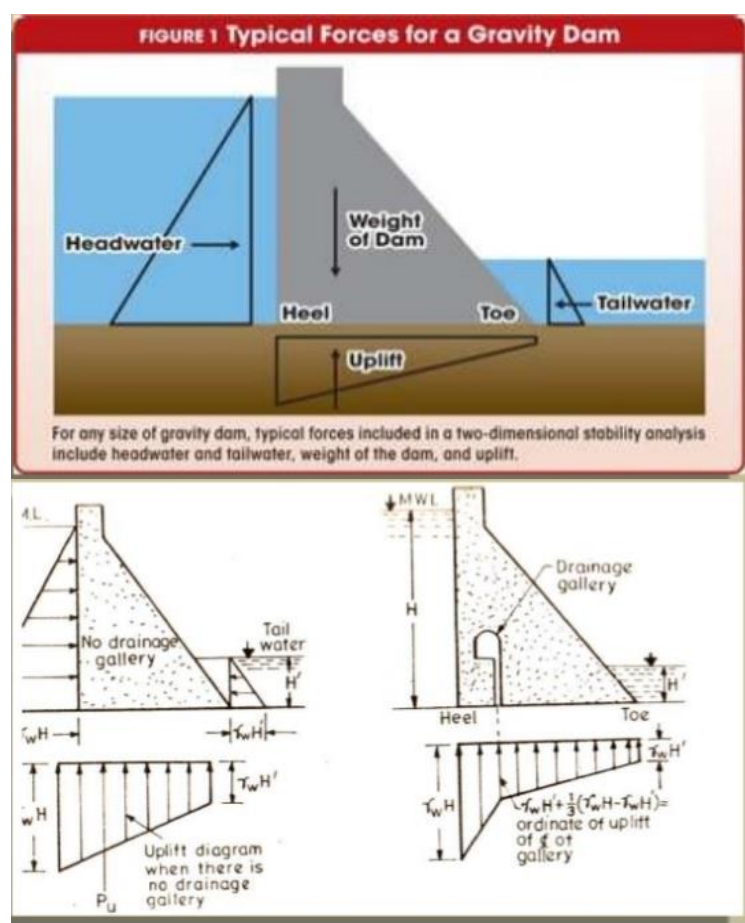

Figure 2

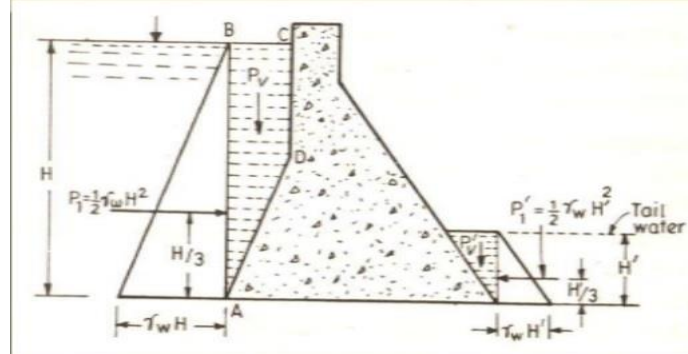

Figure 3

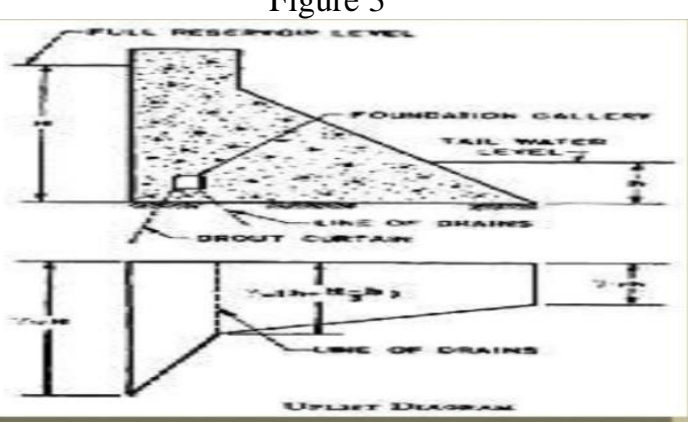

Figure 4

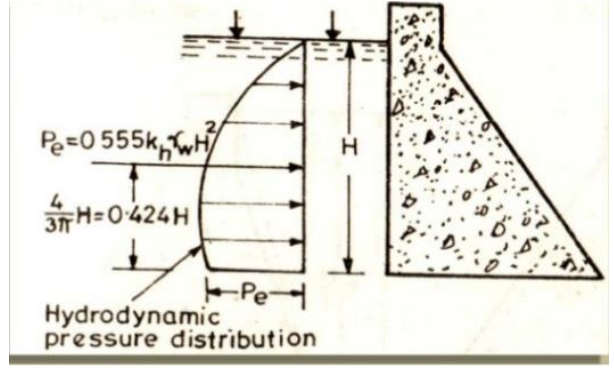

Figure 5

b. Uplifting Pressure: If water seeps through the dam/ reservoir foundation structure; the water pressure subcutaneously lifts the dam/ reservoir structure from its bed. This is one of the principal components looking while studying designing dam stability analysis. The hydro static pressure at heel and toe are calculated and finally the uplift pressure is computed from the Pressure Distribution diagram as follows;

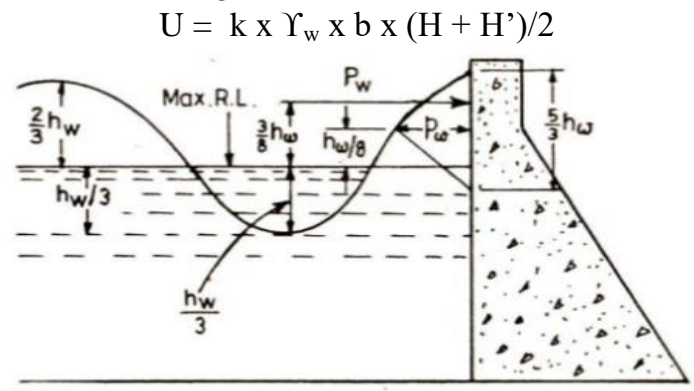

Figure 6

Drainage gallery generally reduces the uplift pressure; the uplift pressure with drainage gallery is given by formula;

$\mathrm{U}=\Upsilon_{\mathrm{w}} \mathrm{x} \mathrm{H}^{\prime}+\left(\Upsilon_{\mathrm{w}} \mathrm{x} \mathrm{H}-\Upsilon_{\mathrm{w}} \mathrm{x} \mathrm{H}^{\prime}\right) / 3$

Wave Pressure:Though, stored water has potential energy; the water is continuously flowing into the dam/ reservoir and possesses Kinetic energy. This induces vibrations and waves. The waves are multiplied even in case of Seismic Failures i.e. Vertical Acceleration and Horizontal Acceleration. Moreover; ice formation etc.

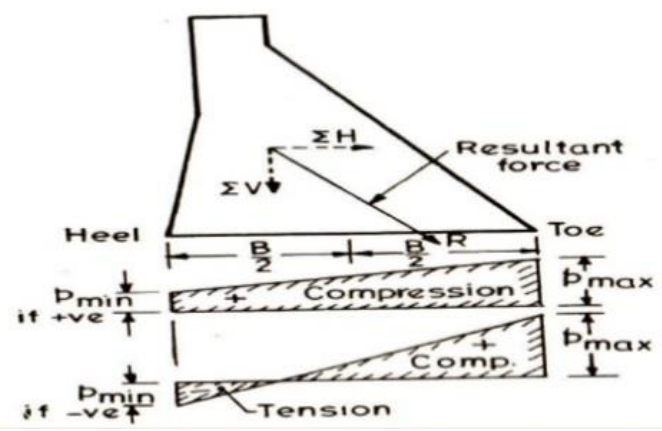

Figure 7

owing to its continuous wav/ (s) slamming on the dam/ reservoir wall causes waves. The maximum crest is $2 / 3^{\text {rd }}$ of height and trough of $1 / 3^{\text {rd }}$ of height.

Stabilizing forces - weight of dam is the stabilizing force for the dam. The Weight of the dam should be more than the vertical components of the forces on the dam. The weight causes compression while horizontal is responsible for tension \& shearing action on the dam/ reservoir gates. 


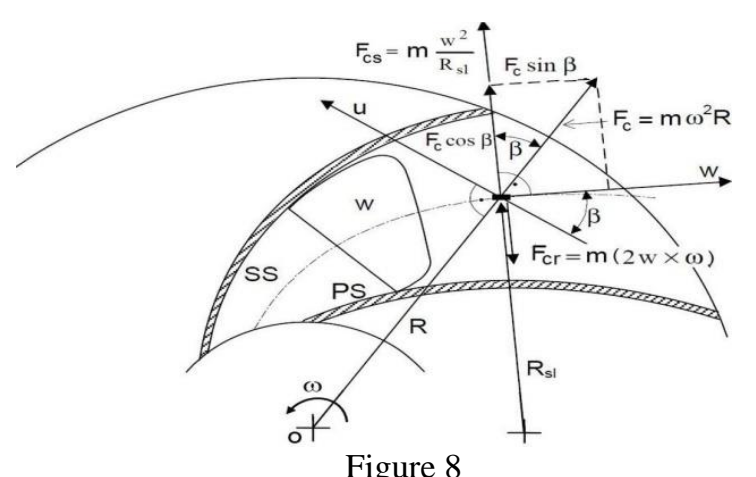

Figure 8

\section{FORCES ACTING ON THE VERTICAL LIFT GATE:}

The downward forces acting on the gate when it is being raised are;

a. Weight of the gate

b. Weight of ballast required to be added for the gate closing under self-weight

c. Friction at the seals (rubber seals and seal plates)

d. Friction at slide blocks/ wheels (roller pin and bushings)

e. Down pull/ up thrust forces acting on the gate The Horizontal Dam Force $\left(\mathrm{F}_{\text {Dam } \mathrm{X}}\right)$ Components dictate the structural stability of the dam gates. The maximum operating load conditions exist under the $\mathrm{F}_{\text {Dam } \mathrm{X}}$. Hence, it could be deduced that;

$$
\Sigma \mathrm{F}_{\text {Dam X }}=\Sigma\left[\mathrm{W}_{\text {gate }}+\mathrm{W}_{\text {ballast }}+\mathrm{F}_{\text {Friction-Seals }}+\mathrm{F}_{\text {Friction-wheels }}+\right.
$$

Factor of safety is assumed to be 6 under normal working conditions. Therefore,

$$
\sigma_{\text {allow }}=\sigma_{\text {yield }} / 6 \text { and } \sigma_{\text {working }}<\sigma_{\text {allow }}
$$

Working stress under full loading must be less than Allowable Stress. Allowable Stress is assumed to be $1 / 6^{\text {th }}$ of Stress at yield point. The upward forces acting on the gate when it is being lowered are;
a. Friction at the seal
b. Friction at the slide blocks
c. Uplift
d. Buoyancy

But for safety reasons; they are assumed to be marginally zero.

\section{FORCES ACTING ON RADIAL GATE:}

Applying Bernoulli Equation to points 1 and 2;

$$
\frac{\mathrm{P}_{1}}{\mathrm{r}}+\frac{\mathrm{V}_{1}^{2}}{2 \mathrm{~g}}+\mathrm{z}_{1}=\frac{\mathrm{P}_{2}}{\mathrm{r}}+\frac{\mathrm{v}_{2}^{2}}{2 \mathrm{~g}}+\mathrm{z}_{2}
$$

$\mathrm{P}_{1}, \mathrm{P}_{2}$ : Pressure at chosen point

$\mathrm{V}_{1}, \mathrm{~V}_{2}$ : fluid flow speed

$\mathrm{Z}_{1}, \mathrm{Z}_{2}$ : elevation of the point above reference plane

g : acceleration due to gravity

$\rho \quad$ : density of fluid at all points in the fluid

In still water conditions; $Z_{1}=Z_{2}$ the above equation becomes;

$$
\mathrm{P}_{2}-\mathrm{P}_{1}=\rho \mathrm{V}_{1}^{2} / 2 \mathrm{~g}
$$

\begin{tabular}{|c|c|c|c|}
\hline $\begin{array}{c}\text { Gate } \\
\text { Opening } \\
(\mathbf{d}) \mathbf{~ m}\end{array}$ & $\begin{array}{c}\text { Height } \\
(\mathbf{\Delta H}) \mathbf{m}\end{array}$ & $\begin{array}{c}\text { Velocity } \\
(\mathbf{V}] \mathbf{~ m} / \mathbf{s}\end{array}$ & $\begin{array}{c}\text { Pressure } \\
\text { Difference } \\
\left(\mathbf{P}_{\mathbf{2}}-\mathbf{P}_{\mathbf{1}}\right) \mathbf{N} / \mathbf{m}^{\mathbf{2}}\end{array}$ \\
\hline 0.5 & 6 & $\mathrm{~V}=\sqrt{ } 2 \mathrm{gh}$ & 58750 \\
\hline 1.0 & 5.5 & $\mathrm{~V}=\sqrt{ } 2 \mathrm{gh}$ & 53950 \\
\hline 2.0 & 4.5 & $\mathrm{~V}=\sqrt{ } 2 \mathrm{gh}$ & 44086 \\
\hline 4.0 & 2.5 & $\mathrm{~V}=\sqrt{ } 2 \mathrm{gh}$ & 24250 \\
\hline
\end{tabular}

\section{ALUMINIUM REINFORCED PANELS ${ }^{[3]}$ :}

Aluminium is a light weight and rust resistant material. Fiber Reinforced Aluminium (FRA) is a mixture of carbon fiber and aluminium. If used together with a phase-change material (PCM), it creates a smart environmental friendly system which is light weight, greater strength than steel structures, economical, effectively reduce carbon foot print etc. Sandwich composite is a type of composite materials that is assembled by bonding of two thin facings on a lighter core where the core used to separate the thin facings. In this type of material the flexural rigidity is increased as the two skin surfaces separates. The objective of using sandwich structured composite materials is to reduce the weight and increase strength and also better excellent thermal insulation properties. Aluminium (Al7075 T6) skin surface is embedded with alternate layers of polyurethane \& acrylate, owing to its shatter resistant properties. Each polyurethane $\&$ acrylate are fused together as single layer. Total six layers are hand layup with ply angle of $28.5^{\circ}$ (using Bevel Protractor).Using Three- point bending test axial compression and lateral crushing loads are evaluated on sandwich composites. Finally results are compared with strength to weight ratio of aluminium rods and aluminium composite panel.

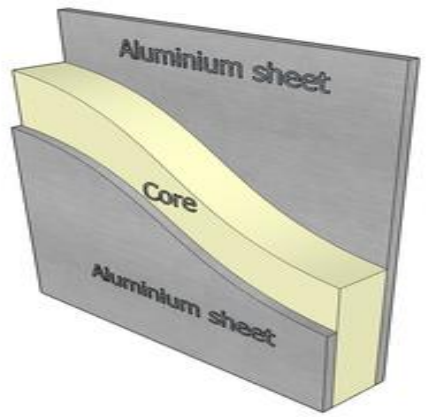

Figure 9

Vertical lift crest gates and radial gates are manufactured using FRA sandwich composite. Crest gates of dimensions $67.4 \times 67.4 \times 67.4 \mathrm{~m}^{3}$ and radial gates $40.44 \times 40.44 \times 13.48$ $\mathrm{m}^{3}$ and $60.66 \times 40.44 \times 13.48 \mathrm{~m}^{3}$ are made. The inclination angle from axis of dam to toe of the gate is $57^{\circ}$. The inclination angle is much higher than angle of repose, indicating free flow downstream.

\section{EXPERIMENTAL SETUP:}

A plexiglass model of the dam/ reservoir with water storage of dimensions $50 \times 48 \times 16.5 \mathrm{~cm}^{3}$ on upstreamside and downstream side of length $50 \times 35 \times 15 \mathrm{~cm}^{3}$ is made. FRA Vertical lift gate of dimensions $10 \times 10 \times 6.5 \mathrm{~cm}^{3}$ is made. Radial Crest Gate of dimensions $6.2 \times 8 \times 5 \mathrm{~cm}^{3}$. The scale of $1 \mathrm{~cm}=8.578 \mathrm{~m}$ is considered in the model design. The total storage capacity of dam/ reservoir is assumed to be 25 x $10^{9}$ litres (equivalent to cultivate 10,000 acres of land downstream) of which $50 \%$ is for agricultural purpose and the $50 \%$ for drinking purposes - of available water resources 
Let,
a. Height of the dam
$\mathrm{H}: 23 \mathrm{~cm}$
b. Height of Water
$\mathrm{h}: 18.5 \mathrm{~cm}$
c. Top of the dam
a : $7.0 \mathrm{~cm}$
d. Bottom of the dam (b)
$: 16.0 \mathrm{~cm}$
e. Weight density of dam masonry $\left(\mathrm{w}_{0}\right)$ :
f. Weight density of water
: $9810 \mathrm{~N} / \mathrm{m}^{3}$
g. Force exerted by water
$\mathrm{F}$

h. Weight of dam per unit meter length of dam W $\mathrm{F}=\mathrm{wAh}=\mathrm{w}(\mathrm{h} * 1) \mathrm{h} / 2=9810 * 0.5 *(0.185)^{2}=167.874 \mathrm{~N}$

Weight of dam/ meter length of dam (W)

$=\mathrm{w}_{0} *((\mathrm{a}+\mathrm{b}) / 2) * \mathrm{H} * 1=\mathrm{w}_{0}[(0.07+0.16) / 2] * 0.23 * 1$ $=0.026 \mathrm{w}_{0}$

$\mathrm{AN}=\left(\mathrm{a}^{2}+\mathrm{b}^{2}+\mathrm{ab}\right) / 3 *(\mathrm{a}+\mathrm{b})$

$=\left[\left(0.07^{2}+0.16^{2}+0.07 * 0.16\right)\right] / 3(0.07+0.16)=0.06 \mathrm{~m}$

$\mathrm{x}^{-}=\mathrm{Fh} / 3 \mathrm{~W}=10.35 / \mathrm{W}$

eccentricity, $e=d-b / 2=[0.06+10.35 / 4-0.16 / 2]$

$$
=10.35 / \mathrm{w}-0.02
$$

$\sigma_{\text {max. }}=\mathrm{W} / \mathrm{b}(1+6 \mathrm{e} / \mathrm{b})=6.25 \mathrm{~W}[0.25+388.125 / \mathrm{w}]$

$\sigma_{\text {min. }}=\mathrm{W} / \mathrm{b}(1-6 \mathrm{e} / \mathrm{b})=6.25 \mathrm{~W}[1.75-388.125 / \mathrm{w}]$

$\rho_{\text {acrylite }}=1.19 \mathrm{gm} / \mathrm{cc}=1.19 \times 10^{3} \mathrm{~kg} / \mathrm{m}^{3}$

Weight of Acrylite $=21.248 \mathrm{~kg}$

$\mathrm{w}_{0}=\rho \mathrm{g}=1.19 \times 10^{3} \times 9.81=11.674 \times 10^{3}$

$\sigma_{\text {max. }}=2628.5 \mathrm{~N} / \mathrm{m}^{2}$

$\sigma_{\min .}=1006.75 \mathrm{~N} / \mathrm{m}^{2}$

\section{VERTICAL LIFT GATES:}

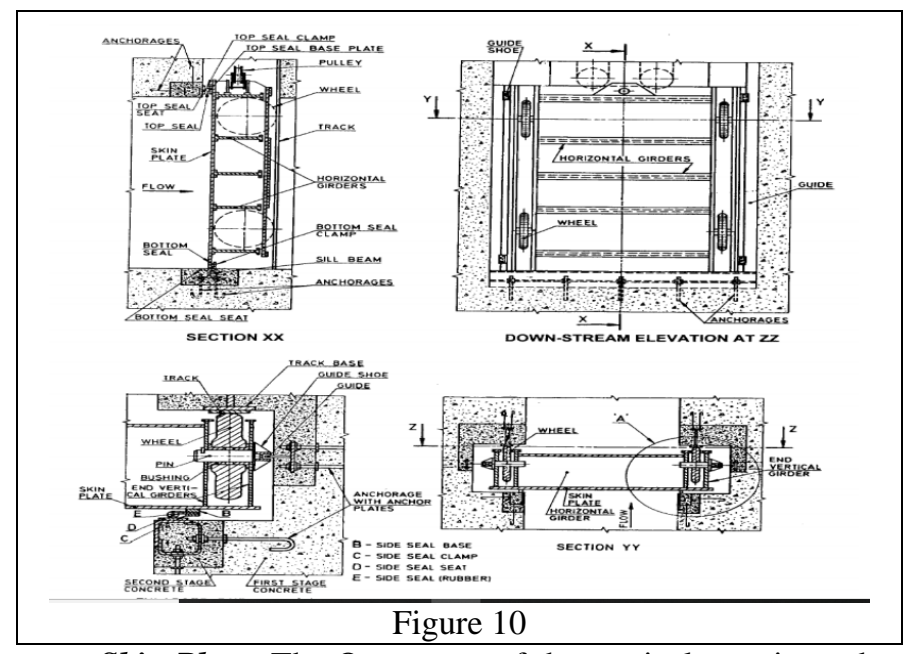

a. Skin Plate: The Outer core of the vertical gate is made of Aluminium of $3 \mathrm{~mm}$ thickness. Hydro dynamic load is applied directly to the aluminium outer core.

b. Vertical Stiffeners: These structural members align with the skin plate and provide vertical stability to the gate structure. Stiffeners of $5 \mathrm{~mm}$ square aluminium Cross section are casted into the outer skin plate. Bending Stresses from skin plate (computed on par with bending of plates) are directly transferred to vertical stiffeners.

c. Horizontal Girders: The horizontal girders provide support to the vertical stiffeners. They are the second line of defence against the hydro dynamic loads \& seismic loads on the skin plate. Seismic loads cause both horizontal and vertical acceleration. Horizontal girders run throughout the width of the gate. Girders above the sill seal are tightly packed while from $\mathrm{H} / 3$ they are sparsely packed depending on the loading conditions. Mesh structure of horizontal girders and vertical stiffeners bring strength and security to various loadings under the dam.

d. End Vertical Girder: This is designed as a continuous beam resting on wheel contact points, with concentrated loads from horizontal girders. Torsional effects are also considered, when accounted for.

e. Wheel Assembly/ Slide Pads: Wheels two each on both sides of the gates are packed together. Tracked wheel assembly is fitted into the gate internal structure for ease of operation. Free rotating members for shafts and wheel assemblies are aligned in casting process. Tracks are constructed on the side walls of the inner gate walls for resistive load applications; while lifting or closing the gates.

\section{HOIST MECHANISM ${ }^{[4]}$ :}

Hydraulic Hoist mechanism operates at pressure limit of 70 $\mathrm{kg} / \mathrm{cm}^{2}$. BIS Code IS: 10210 specifies a design pressure range between $10-20 \mathrm{~N} / \mathrm{mm}^{2}$. DIN 19704 permits a maximum pressure of 220 bar for loading under normal conditions. Hoists used for spillway service gates are normally operated around $0.3-0.7$ Meters/ min; while penstock gates are operated at $2 \mathrm{~m} / \mathrm{min}$. and lifting/ lowering $5-10 \mathrm{~m} / \mathrm{min}$ for emergency closure. Poly Tetra Floro ethylene (PTFE) and its compounds are used for sliding elements and poly urethane for elastic packing material. These seals offer low friction and smooth sliding even at very low or high rubbing speeds.

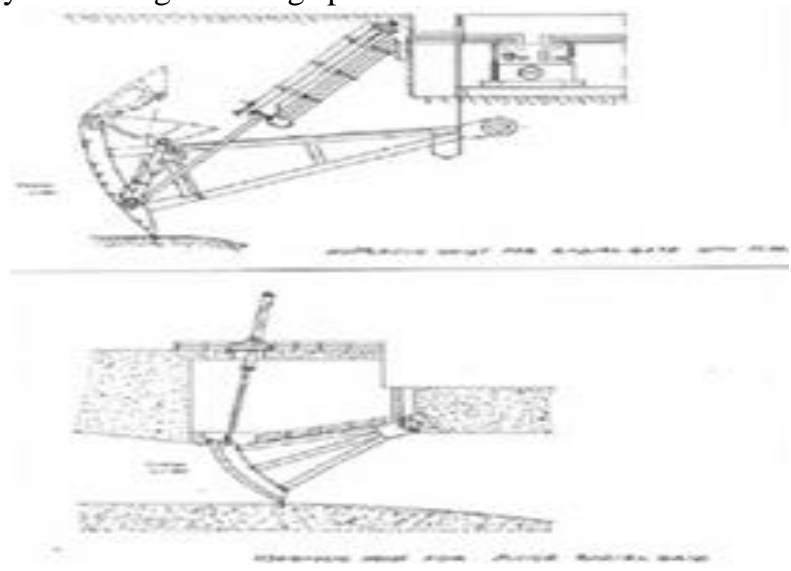

Figure 10 
International Journal of Research in Advent Technology, Vol.7, No.3, March 2019

E-ISSN: 2321-9637

Available online at www.ijrat.org

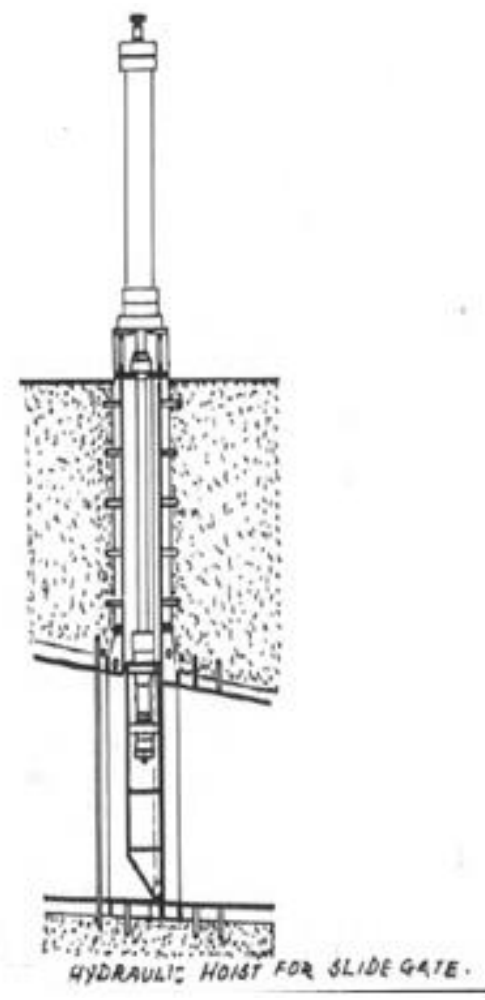

Figure 11

\section{LOAD COMPUTATION \& ANALYSIS OF RADIAL GATE}

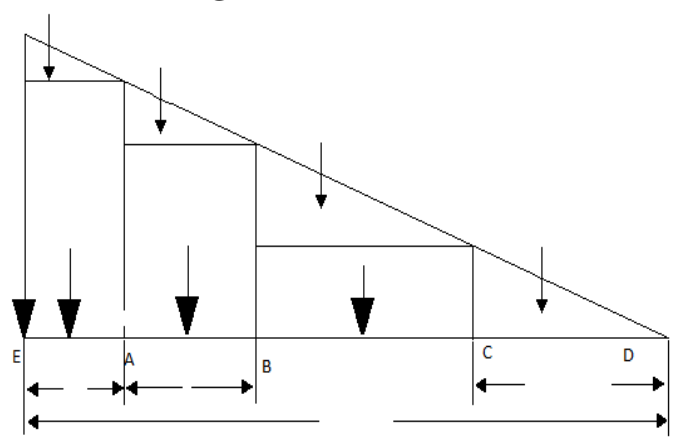

Gate Resting on Sill and Water Load is upto FRL

B

\begin{tabular}{|c|c|c|c|c|c|c|}
\hline Joint Member & 0 & 1 & 0.563 & \begin{tabular}{|l|l|} 
& 0.437 \\
\end{tabular} & 1 & 0 \\
\hline $\begin{array}{l}\text { Fixed End Moments } \\
\text { Balance } \\
\text { Carry Over }\end{array}$ & +9.032 & $\begin{array}{l}-10.053 \\
+1.021\end{array}$ & $\begin{array}{l}+9.344 \\
+0.511\end{array}$ & $\begin{array}{l}-10.114 \\
-0.383\end{array}$ & $\begin{array}{l}+8.621 \\
-0.765\end{array}$ & -7.856 \\
\hline Total Distribution & $\mid 9.032$ & -9.032 & $\begin{array}{l}+9.855 \\
+0.361\end{array}$ & $\begin{array}{l}-10.497 \\
-0.281\end{array}$ & +7.856 & -7.856 \\
\hline Net Moments in tm & +9.032 & -9.032 & +10.216 & -10.216 & +7.856 & -7.856 \\
\hline $\begin{array}{l}\text { SF due to Moments } \\
\text { in } \mathrm{t} \\
\mathrm{SF} \text { due to loads in } \mathrm{t}\end{array}$ & \begin{tabular}{|l|l|}
0 \\
+14.586
\end{tabular} & $\begin{array}{l}-0.338 \\
+17.640 \\
\end{array}$ & $\begin{array}{l}+0.338 \\
-15.612 \\
\end{array}$ & $\begin{array}{l}+0.524 \\
+14.149 \\
\end{array}$ & $\begin{array}{l}-0.524 \\
+10.831 \\
\end{array}$ & $\begin{array}{l}0 \\
+6.164 \\
\end{array}$ \\
\hline Shear Forces in $\mathrm{t}$ & +14.586 & +17.302 & +15.950 & +14.673 & +10.307 & +6.164 \\
\hline
\end{tabular}

Figure 12

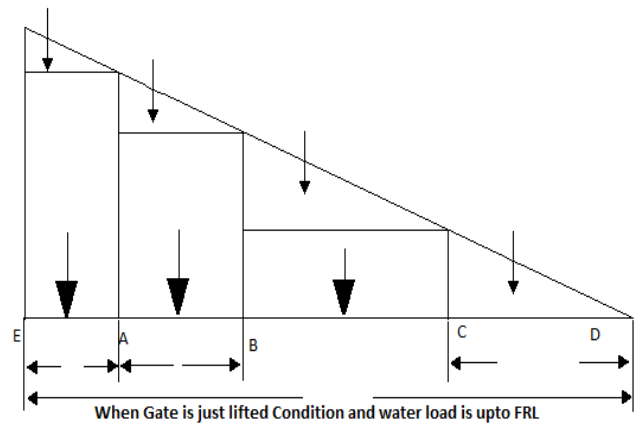

\begin{tabular}{|c|c|c|c|c|c|c|}
\hline Joint Member & 0 & 1 & 0.563 & $\mid 0.437$ & 1 & 0 \\
\hline $\begin{array}{l}\text { Fixed End Moments } \\
\text { Balance } \\
\text { Carry Over }\end{array}$ & +7.228 & $\begin{array}{l}-10.053 \\
+2.825\end{array}$ & $\begin{array}{r}+9.344 \\
+1.413\end{array}$ & $\begin{array}{l}-10.114 \\
-0.383\end{array}$ & $\begin{array}{l}+8.621 \\
-0.765 \\
-\end{array}$ & -7.856 \\
\hline Total Distribution & +7.228 & -7.228 & $\begin{array}{l}+10.757 \\
-0.146\end{array}$ & $\begin{array}{r}-10.497 \\
-0.114\end{array}$ & +7.856 & -7.856 \\
\hline Net Moments in tm & +7.228 & -7.228 & +10.611 & -10.611 & +7.856 & -7.856 \\
\hline $\begin{array}{l}\text { SF due to } \\
\text { Moments in } t \\
\text { Reactions in } t\end{array}$ & $\begin{array}{l}0 \\
+12.946\end{array}$ & $\begin{array}{l}-0.967 \\
+17.640\end{array}$ & $\begin{array}{c}+0.967 \\
15.612\end{array}$ & $\begin{array}{r}+0.612 \\
+14.149 \\
\end{array}$ & $\begin{array}{c}-0.612 \\
+10.831 \\
\end{array}$ & $\begin{array}{l}0 \\
+6.164\end{array}$ \\
\hline \multirow[t]{2}{*}{ Shear Forces in $\mathrm{t}$} & +12.946 & +16.673 & ${ }_{+16.579}$ & ${ }^{+} 14.761$ & ${ }^{+} 10.219$ & +6.164 \\
\hline & 29.619 & $\mathrm{t}$ & $31.34 t$ & $Z_{\mathrm{R} 1} \mathrm{~N}$ & 16.2 & \\
\hline
\end{tabular}

Figure 13

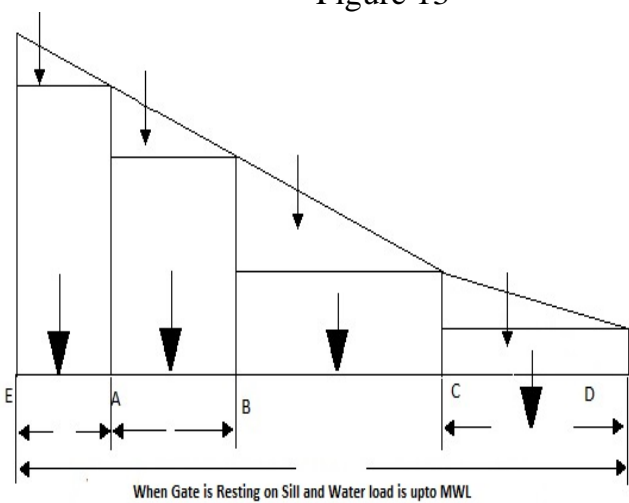

\begin{tabular}{|c|c|c|c|c|c|c|}
\hline Joint Member & 0 & 1 & 0.563 & 0.437 & 1 & 0 \\
\hline $\begin{array}{l}\text { Fixed End Moments } \\
\text { Balance } \\
\text { Carry Over }\end{array}$ & +9.395 & $\begin{array}{l}-10.665 \\
+1.270\end{array}$ & $\begin{array}{l}+9.956 \\
+0.635\end{array}$ & $\begin{array}{l}-11.127 \\
+1.489\end{array}$ & $\begin{array}{l}+9.633 \\
+2.977 \\
+\end{array}$ & -12.610 \\
\hline Total Distribution & +9.395 & $-9,395$ & $\begin{array}{r}+10.591 \\
-0.622\end{array}$ & $\begin{array}{l}-9.638 \\
-0.331\end{array}$ & +12.610 & -12.610 \\
\hline Net Moments in tm & +9.395 & -9.395 & +9.969 & -9.969 & +12.610 & -12.610 \\
\hline $\begin{array}{l}\text { SF due to } \\
\text { Moments int } \\
\text { Reactions int }\end{array}$ & $\begin{array}{r}0 \\
+15.246 \\
\end{array}$ & $\begin{array}{r}-0.164 \\
+18.689 \\
+\end{array}$ & $\begin{array}{r}+0.164 \\
+16.662 \\
\end{array}$ & $\begin{array}{r}+0.587 \\
+15.499 \\
\end{array}$ & $\begin{array}{r}-0.587 \\
+12.181 \\
\end{array}$ & $\begin{array}{r}0 \\
+8.639 \\
\end{array}$ \\
\hline Shear Forces in $\mathrm{t}$ & $\mid+15.246$ & +18.525 & +16.826 & +14.912 & +12.768 & +8.639 \\
\hline
\end{tabular}

Figure 14 
International Journal of Research in Advent Technology, Vol.7, No.3, March 2019

E-ISSN: 2321-9637

Available online at www.ijrat.org

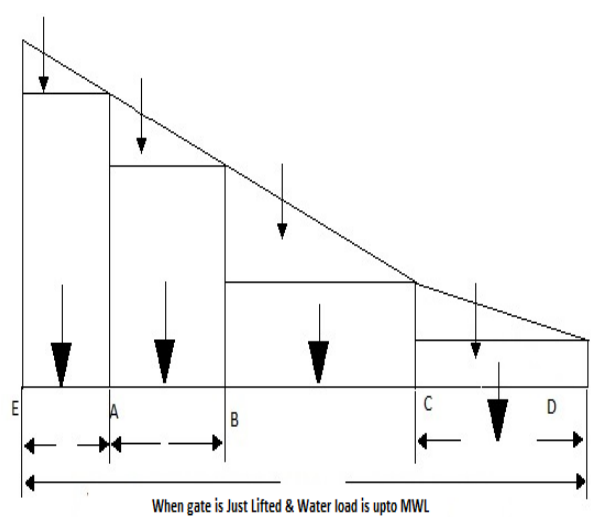

\begin{tabular}{|c|c|c|c|c|c|c|}
\hline & \multicolumn{2}{|c|}{ A } & \multicolumn{2}{|c|}{ B } & \multicolumn{2}{|l|}{ C } \\
\hline Joint Member & 0 & 1 & 0.563 & \begin{tabular}{|l|l|} 
& 0.437
\end{tabular} & 1 & 0 \\
\hline $\begin{array}{l}\text { Fixed End Moments } \\
\text { Balance } \\
\text { Carry Over }\end{array}$ & +7.591 & $\begin{array}{l}-10.665 \\
+3.074\end{array}$ & $\begin{array}{r}+9.956 \\
+1.537\end{array}$ & $\begin{array}{l}-11.127 \\
+1.489\end{array}$ & $\begin{array}{l}+9.633 \\
+2.977\end{array}$ & -12.610 \\
\hline Total Distribution & +7.591 & -7.591 & $\begin{array}{l}+11.493 \\
-1.044\end{array}$ & $\begin{array}{l}-9.638 \\
-0.811\end{array}$ & +12.610 & .12 .610 \\
\hline Net Moments in tm & +7.591 & -7.591 & +10.449 & -10.449 & $+12,610$ & -12.610 \\
\hline \begin{tabular}{|l} 
SF due to \\
Moments int \\
Reactions int
\end{tabular} & $\begin{array}{c}0 \\
+13.606 \\
\end{array}$ & $\begin{array}{l}-0.816 \\
+18.689 \\
\end{array}$ & $\begin{array}{r}+0.816 \\
+16.862\end{array}$ & $\begin{array}{l}-0.480 \\
+15.499 \\
\end{array}$ & $\begin{array}{r}+0.480 \\
+12.181 \\
\end{array}$ & $\begin{array}{c}0 \\
+8.639 \\
\end{array}$ \\
\hline \multirow[t]{2}{*}{ Shear Forces in $t$} & +13.606 & +17.873 & +17.478 & +15.019 & +12.661 & +8.639 \\
\hline & \multicolumn{2}{|c|}{$33.771 \mathrm{t}$} & \multicolumn{2}{|c|}{$31.738 \mathrm{t}$} & \multicolumn{2}{|l|}{21.3001} \\
\hline
\end{tabular}

Figure 15

\section{MECHANICAL TESTS FOR INNER COMPOSITES MATERIALS}

1. Tensile Strength: The tensile test specimen was manufactured and evaluated as per ASTM standards undergone on a universal testing machine. The dimensions of tensile specimens are $150 \mathrm{~mm} * 12 \mathrm{~mm} * 18 \mathrm{~mm}$.Generally, the specimen used for evaluation is in shape of dog-bone type.

2. Compressive Test: A compression test determines the maximum amount of compressive load of a material before fracture. The specimen is evaluated as per ASTM standards. The specimens were prepared with dimensions of $150 * 12 * 18 \mathrm{~mm}$.

3. Impact Test: A Test specimen of $10 * 10 * 75 \mathrm{~mm}$ of composite material (inner core) is tested for its impact strength using Izod Test.

An optimal design of lifting mechanism that is efficient, effective and well-equipped with trustable mechanism and proficient control system lift the gate is vital from the technical perspective of the problem \& eventually for public site. Electricity driven, connected shafting, completely bounded gear reduction, protected and elastic couplings, indented drums, and toughen stainless steel cables

\section{RESULTS AND DISCUSSION}

The composite samples are tested using universal testing machines to determine the tensile, flexural and compressive properties. The strength of composite samples generated with respect to various sandwich structures to be reinforced with different core materials are analyzed. The results indicated that polyurethane based sandwich panels tend to have better tensile and compressive load bearing capacity as compared to Aluminium Honeycomb due to their structure and also Aluminium has better flexural properties because of its core line up which can undertake bending easily.

\section{CONCLUSION:}

The various mechanical tests which were conducted on the samples are 3 Point Bending Test, Tensile Test and Compression Test. All these mentioned tests were conducted by adhering to ASTM standards for testing of composites materials. For the Bending Test it was observed that Aluminium Honeycomb has the highest Bending Load of $1.87 \mathrm{KN}$ and HDPU Foam has the least $0.47 \mathrm{KN}$. This shows that Aluminium Honeycomb has flexural strength 4 times more than that of HDPU Foam. For the Tensile Test it was observed that as Aluminium Honeycomb can easily tear in linear loading, the value of Tensile Load is least for it $1.37 \mathrm{KN}$ and Rohacell which had stronger bonding among the particles, due to is chemical composition has the highest value of Tensile Load at 2.67 which is almost 2 times the value of Aluminium Honey Comb. For Compressive Test, the value of compressive load is highest for Rohacell foam based sandwich panels and HDPU Based panels have a similar behaviour due to the chemical bonds of the foams which bind them together while loading along the axis. In case of Aluminium Honeycomb the value falls to $4.49 \mathrm{KN}$ which is lesser as it tends to crush easily when compressed.

\section{ACKNOWLEDGEMENTS:}

We would like to thank Ms. M. Chaitanya Mayee, Head of Department, Dept. of Mech. Engineering for invaluable support in pursuing this project. Special mention to students, staff of the Mech. Engineering Department; without whose help this paper would not had seen reality.

\section{REFERENCES:}

[1] MurkarMandar Santos, Naik Anjali Sajuram, Patankar Bhakti Santosh, "Water Level Monitoring and Dam Gate Control over IOT", International Journal on Future Revolution in Computer Science \& Communication Engineering, Vol. 4, Issue 4, ISSN 2454-4248, pp. 141 145, Apr.' 2018

[2] E. Nanda Kumar, S. Vimalraj, " Dam Gate Level Monitoring and Control over IoT ", Jour of Adv Research in Dynamical \& Control Systems, Vol. 12, Special Issue, ISSN: ISSN 1943-023X, August 2017

[3] BoguslawPierozynski, "Electrodeposition of Nickel onto 12K Carbon Fibre Tow in a Continuous Manner", CROATICA CHEMICA ACTA, ISSN 0011-1643, pp. $1-8,2012$

[4] Shankareppagol LM, AkshayBajirao C, YuvrajPraksh J, Radhika Ramesh P, SamruddhiSuryawanshi S, and SuhasShankarrao H, "Review on IoT Based Dam Parameters Monitoring System", Journal of Information Technology \& Software Engineering, Vol. 8, Issue 5, ISSN: 2165-7866, 2018

[5] MukhaladKadimNahi, "Design and Analysis of Lifting Mechanism in Water Dams Using Composite Materials", International Journal of Applied Engineering Research, Volume 13, Number 13, ISSN 0973-4562, pp. 11045-11053, 2018 